\title{
PROMOTING FIRM INNOVATIVENESS THROUGH SERVANT \\ LEADERSHIP AND CORPORATE SOCIAL RESPONSIBILITY TO \\ EMPLOYEES
}

\begin{abstract}
Purpose. This paper focus on the relationship between servant leadership and firm innovativeness, as well as the underlying mechanisms that explain this relationship. More concretely, we analyse the relationship between servant leadership, firm innovativeness and corporate social responsibility to employees.
\end{abstract}

Design/methodology/approach. A total of 285 Spanish firms took part in the study and 570 questionnaires were gathered. Structural equations were used to validate the proposed hypotheses.

Findings. Results suggest that servant leadership has a positive relationship with firm innovativeness and this relationship is fully mediated by corporate social responsibility to employees.

Research limitations/implications. HR managers have an overall view of their company and of the behaviour of other leaders. However, future research should also consider employees perceptions. The present study is cross-sectional and it would be interesting to study the development of the interaction between leaders and followers, which calls for longitudinal and multilevel studies.

Practical implications. According to our results, managers could foster firm innovativeness if they select and promote leaders who display the different leadership behaviours related to servant leadership: empowerment, servitude, accountability, 
courage, authenticity, humility and stewardship. Moreover, training programmes should also foster these behaviours.

Originality/value. Few empirical studies analyse the relationship between servant leadership and innovation. The main contribution of the present research is to further the current knowledge of this relationship by disentangling the mediating role of corporate social responsibility to employees.

Keywords: servant leadership; corporate social responsibility; CSR; innovativeness; corporate social responsibility to employees 


\section{Introduction}

Firm innovativeness is vital to firm survival, success and competitive advantage (Khazanchi, 2007; Varadarajan, 2009). Innovativeness or innovation capacity is considered as the openness of an organisation to new ideas, new ways of doing things, creativity, etc., which gives the organisation the chance to be the first to market new products and services (Calantone et al., 2002). However, the pursuit of firm innovativeness can be challenging and entails a series of costs. In this sense, firms differ in their degree of innovativeness because of the tension between the need to be innovative and the costs involved in making innovations happen (Prasad \& Junni, 2017). Some scholars have recently explored the reasons why some firms are more innovative than others and have found that firm innovativeness is linked to organisational and managerial determinants (e.g. Atuahene-Gima, 2003; Prasad \& Martens, 2015).

Leadership style is one of the most important individual factors that promote firm innovation (Aragón-Correa et al., 2007; Mumford, 2002). Leaders can take decisions to introduce new ideas into the organisation, set specific goals and encourage innovation among their subordinates (Aragón-Correa et al., 2007). They can also create an environment in which employees feel protected, take risks and are therefore more inclined to innovate (Nutt, 2002). According to Topcu (2015), managers should be encouraged to use leadership methods and create a convenient organisational climate which triggers employees' innovative behaviours.

Sendjaya et al. (2008: 402) summarised some chronic problems related to organisational leaders, such as bullying leadership, abuse of power, unethical practices, toxic emotions, social isolation and alienation in the workplace, and the violation of 
employees' psychological well-being and work-life balance. In contrast, there is an increasing demand for organisations to be people-oriented and managed ethically, achieving their goals from a moral point of view (Rodríguez-Carvajal et al., 2014). Van Dierendonck (2011) stated that, when studying leadership, more emphasis needs to be placed on social responsibility in order to facilitate the organisation's success. This shift in the study of leadership has been reflected in an increased interest in servant leadership, as it highlights the followers' interests and morality (Peterson et al., 2012). In this context, servant leadership emerges as a leadership approach that is more relevant and timely than other value-laden leadership approaches (Sendjaya et al., 2008). Furthermore, Williams et al. (2017) pointed out that the number of empirical studies conducted using the servant leadership construct is insufficient.

Some authors have focused on the study of the antecedents of servant leadership. For example, Barbuto et al. (2014) found a positive relationship between emotional intelligence and servant leadership, and Flynn et al. (2016) studied the influence of leaders' core self-evaluations on this leadership style. Another stream of research has identified the relationship between servant leadership and both individual and organisational outcomes, such as creative behaviours, job satisfaction and organisational commitment, among others (e.g. Hunter et al., 2013).

According to Williams et al. (2017), servant leadership is a suitable concept to promote creativity in the current context of knowledge and innovative organisations, as it serves the needs of the followers in an authentic and empowering manner. Van Dierendonck (2011) proposed that both innovation and employee well-being should be given high priority and so leadership that is rooted in ethical and caring behaviours, such as servant leadership, becomes of great importance. Gilley et al. (2011) described servant 
leaders as equal partners who, through a participatory approach, work alongside employees to promote individual and organisational success. Recent studies have found a significant relationship between servant leadership and innovation (e.g. Yang et al., 2017; Yoshida, 2014). However, to the best of our knowledge, little research has explored the underlying mechanisms that explain this relationship. Panaccio et al. (2015) stated that previous research did not clarify the psychological mechanisms and the boundary conditions in which servant leadership promotes different outcomes. Previous studies identified that the influence of servant leadership on different outcomes, including creativity, may be indirect. It is therefore necessary to study the mediating mechanisms in the relationship between servant leadership and different outcomes (Liden et al., 2014; Yang et al., 2017). Servant leadership places emphasis on the personal growth of followers and adds the component of social responsibility to transformational leadership (Graham, 1991).

Corporate social responsibility (CSR) offers a specific and focused context in which to explore leader impacts (Christensen, 2014: 175). However, the two disciplines have rarely been combined in the academic field, despite the acknowledged importance of studying the antecedents and consequences of CSR, focusing on how leaders affect this activity. Among the new leadership styles, servant leadership is the most appropriate style to move theory about CSR forward (Christensen, 2014).

Additionally, CSR is positively related to innovation (Mishra, 2017). Bammens (2016), however, stated that the study of how social aspects of the work context, which include promoting employee well-being, influence innovation remains underdeveloped. Chen et al. (2016b) pointed out that little attention has been paid to how employeefriendly workplaces foster innovation. In addition, Chen et al. (2016b) asserted that, 
despite this positive relationship, CSR comprises numerous dimensions that must be studied separately. It is unclear whether all dimensions are beneficial for innovation, so combining several dimensions may give an incomplete understanding of how innovation is fostered within firms. Therefore, these authors recommend focusing on a specific dimension of CSR when studying its influence on innovation. In this paper, we focus on CSR to employees (CSRE).

Based on the above lines, the conceptual model shown in Figure 1 is proposed. The contention of our model is that the effect of the servant leader on innovativeness is mediated by CSRE. Accordingly, three hypotheses representing (a) the relationship between servant leadership and CSRE, (b) the relationship between CSRE and innovativeness, and (c) the relationship between servant leadership, CSRE and innovativeness are developed and tested.

\section{PLACE FIGURE 1 HERE}

In the following sections, a review of the literature about servant leadership and CSRE is conducted. Considering previous research, relationships among these constructs and firm innovativeness are also established. Subsequently, details of the methodology used to analyse the proposed hypothesis are provided. The study finishes with the presentation of results, conclusions, suggestions for future research and evaluation of the limitations of the present research. 


\section{Literature review and hypotheses}

\subsection{Servant leadership}

Servant leadership is an ethical leadership style that focuses on people, introduces a moral component and prioritises followers' needs (Van Dierendonck, 2011). It puts the interests of the followers before those of the organisation, and is focused on employees and their welfare, cares about them and seeks their development (Choudhary et al., 2013; Rodríguez-Carvajal et al., 2014), which together help to fully develop their potential (Van Dierendonck and Patterson, 2015). Servant leadership emphasises that leaders not only have a responsibility in the success of the organisation but also a moral obligation with different stakeholders, including society in general (Peterson et al., 2012; Williams et al., 2017). In fact, the main difference between servant leadership and other leadership styles, such as transformational, is that these leaders prioritise followers' needs over organisational goals (Van Dierendonck, 2011). Servant leaders encourage followers to engage in moral thinking (Peterson et al., 2012). When leaders care about followers' interests, they are motivated to act in the same way and go beyond self-interest. Being a servant leader is a conscious decision (Van Dierendonck and Patterson, 2015).

There are different scales to measure servant leadership, which include diverse dimensions (e.g. Sendjaya et al., 2008; Van Dierendonck and Nuijten, 2011). RodríguezCarvajal et al. (2014) validated Van Dierendonck and Nuijten's (2011) scale in Spain. This scale is made up of the following dimensions: empowerment, accountability, standing back, humility, authenticity, courage, forgiveness (acceptance of others) and stewardship. The different dimensions that make up servant leadership serve to define this leadership style in a broad sense, although all of them may not have the same importance (Van Dierendonck \& Patterson, 2015; Van Dierendonck and Nuijten, 2011). 
According to Rodríguez-Carvajal et al. (2014), empowerment allows employees to have more power and control over their own work; accountability implies that workers are responsible for the consequences and outcomes of their decisions; servitude is the ability to remain in the background, allowing others to take compliments; humility is related to the capability to properly evaluate one's own abilities and achievements in a reasonable manner, being aware of the fact that nobody is infallible and may make mistakes; stewardship looks beyond self-interest and is concerned about the consequences of entrepreneurial activity; forgiveness refers to the ability of leaders to empathise with their employees and understand their circumstances, to be able to forgive their disputes and mistakes. Van Dierendonck (2011) stated that authenticity is to be oneself, expressing real feelings and opinions, and prioritising what anyone is as a person instead of as a professional; finally, courage is related to the willingness to take risks, searching for alternatives to problems and questioning old patterns.

\subsection{CSR to employees}

The first references to the concept of CSR emerged in the 1950s (Bowen, 1953) and since then the concept has been developed extensively. It has been defined in different ways and it is difficult to find a commonly accepted definition. CSR is a voluntary contribution of business to achieve a fairer and more sustainable economy, society and environment (Delgado and Gallardo-Vázquez, 2016), going beyond compliance with laws (Newman et al., 2016) and promoting a positive impact on the stakeholders (Turker, 2009). Turker (2009) defined CSR as "corporate behaviours that aim to affect stakeholders positively and that go beyond [the organisation's] economic interest". Although CSR is a multifaceted construct, previous research did not pay much attention 
to distinguishing types of CSR (Mishra and Modi, 2016). Different authors propose different dimensions or types of CSR, but all these classifications have in common a dimension referring to the employees. For example, Mishra and Modi (2016) suggested six CSR types: environment-, product-, diversity-, corporate governance-, employee- and community-based philanthropic efforts. Turker (2009) conceptualised CSR with four dimensions: responsibility to social and non-social stakeholders (society, natural environment, future generations, NGOs), employees, customers and government.

Employees are especially important in the social dimension of CSR (Delgado and Gallardo-Vázquez, 2016), and previous research has highlighted the relevance of taking care of these stakeholders due to their essential role in the success of organisations. For instance, Rodrigo and Arenas (2008) stated that one stakeholder that must always be considered in CSR is employees, although it is a group that has received little attention compared to other stakeholders.

As in the case of CSR, neither is there a single definition of CSRE (Celma et al., 2014). In the literature we can find related or similar concepts such as responsible human resource management or moral management of employees (Celma et al., 2014; Newman et al., 2016). CSRE improves employees' welfare and addresses their concerns (Newman et al., 2016). According to Turker (2009), CSRE involves policies that encourage employees to develop their skills and careers, management concerned with employees' needs and wants, implementation of flexible policies that provide a good work and life balance for their employees, taking decisions that are usually fair with the employees, and providing support to employees who want to acquire additional education. 
Similarly, Celma et al. (2014) stated that CSR in human resource management tries to strengthen job quality, through motivated and trained employees who may develop their skills and achieve a work-life balance. These programmes are not limited to salaries or bonuses but also comprise policies aimed at treating employees better, including flexible schedules or improved work conditions (Chen et al., 2016). Socially responsible human resource management strengthens employees' capacities through education, training and safety practices (Delgado and Gallardo-Vázquez, 2016). Flammer and Luo (2017) stated that employee-related CSR programmes align the incentives between employees and the firm, and include investments in work-life balance, health and safety, and employee involvement. These authors stated that these programmes, compared to monetary incentives, are difficult to imitate. Therefore they can be used as a tool to motivate employees, decrease the attractiveness of other jobs, attract a higherquality workforce, retain talented employees and improve their engagement, fuel employees' perception of their jobs, foster employees' engagement and commitment to organisational values and practices and increase job productivity or reduce the possibility of adverse behaviour. Mishra and Modi (2016) consider that employee-based CSR is reflected in firm support to unions and recognition of employees' needs (for instance, providing better wages and retirement benefits) and it may help to retain talented workers.

\subsection{Servant leadership and CSR to employees}

One of the highest priorities of servant leaders is service to others, either inside or outside the organisation, followers' growth being a priority goal (Williams et al., 2017). Employee well-being is essential for servant leaders (Van Dierendonck, 2011). 
Incorporating ethical principles from corporate social responsibility into human resources management practices allows for a clearer focus on worker well-being (Celma, 2014).

Servant leadership emphasises sustainability and corporate social responsibility by focusing on creating a great place to work rather than on achieving high returns on investments (Van Dierendonck, 2011). Leadership qualities that are likely to support corporate responsible behaviour within organisations are related to servant leadership patterns, such as recognising that business does have responsibilities to the broader society, being open, honest and trustworthy, maintaining an open mind, etc. These leaders respect employees at all levels, are committed to employees' growth and development, respect diversity and equal opportunities for all, and so forth (Hind, 2009).

All the above considerations lead us to formulate our first hypothesis:

H1: Servant leadership has a positive effect on corporate social responsibility to employees

\subsection{CSR to employees and firm innovativeness}

CSRE plays a salient role in nurturing a corporate culture that is perceived to focus on employee development and innovation, among other variables (Anthony \& Hong, 2014). Firms that implement employee-friendly policies and foster satisfying workplaces invest more in innovation and achieve greater innovative success, thereby strengthening the relationship between firm and subordinates, enhancing employees' job satisfaction, improving trust in management, experimentation or tolerance of failure (Chen et al., 2016b). Chen et al. (2016) found that better employee treatment schemes are associated with both a higher quantity and quality of innovation. 
CSRE entails supporting workers who want to acquire additional education, encouraging employees to develop their skills and careers, implementing flexible policies to provide a good work and life balance, supporting employees' needs and wants, and taking decisions related to employees which are usually fair (Turker, 2009). These features have been positively related to the development of innovation capability within organisations. For instance, investing in workers' skills through training programmes boosts innovation (González, 2016), and a good work-life balance enhances learning and innovation processes within and among firms (James, 2014). Therefore, we pose the second hypothesis of the study:

H2: CSRE has a positive effect on firm innovativeness

\subsection{Servant leadership and firm innovativeness: The mediation role of CSRE}

Previous research has evidenced a positive relationship between servant leadership and both creativity and innovation (e.g. Yang, 2017; Yoshida, 2014). According to Williams et al. (2017), servant leaders are focused on serving the needs of followers in such an authentic and empowering manner that this leadership style is well suited to knowledge-rich and innovation-intensive organisations. Additionally, the different dimensions that make up servant leadership are also related to innovation. For instance, courage is essential for innovation and creativity as it challenges conventional models of working behaviours (Van Dierendonck \& Nuijten, 2011). Empowerment is a means for leaders to promote change in their organisations (Conger \& Kanungo, 1988), thereby making employees more likely to be motivated to be creative and suggest new ideas that may result in more change and innovation (Seibert, 2011). Through forgiveness it is possible to create a climate that reinforces interpersonal relationships, 
communication, risk-taking, creativity and innovation (Caldwell \& Dixon, 2010; Stone, 2002). Stewardship is positively related to creativity (Kuppelweiser, 2011), as concern for sustainability and social problems demands more innovation (Shevchenko, 2016). Finally, authentic leaders enhance creativity and, in turn, innovation (Müceldili et al., 2013).

Leadership is essential for employees' engagement and their innovation (Van Dierendonck \& Nuijten, 2011). Servant leaders support their subordinates and are committed to their growth and development, thus facilitating a context where employees feel safe to use their knowledge and are focused on continuous development and learning (Van Dierendonck, 2011), which may promote innovation. Therefore, this allows us to formulate our last hypothesis:

H3: The relationship between servant leadership and firm innovativeness is mediated by CSRE

\section{Research methodology}

\subsection{Data collection}

The study focuses on a population of 11,594 Spanish firms from a list provided by the Spanish Ministry of Economy and Competitiveness. The fieldwork was carried out in 2015 and data were gathered by telephone interviews. 285 companies participated satisfactorily in the study. Therefore, assuming a 95\% confidence level, sampling error is $+/-5.7 \%$. In order to prevent common method variance, the human resource manager and the general manager each answered different questionnaires (Chang et al., 2010). The former answered questions related to servant leadership and the latter responded on the 
items dealing with CSRE and firm innovativeness. In sum, 570 questionnaires were collected. All the items were measured on a seven-point Likert scale reflecting the degree of agreement or disagreement with the item.

\subsection{Measurement instruments}

\subsubsection{Servant leadership}

This scale was based on the work by Rodríguez-Carvajal et al. (2014), who adapted the Servant Leadership Survey by Van Dierendonck and Nuijten (2011) to Spanish speakers. Rodríguez-Carvajal et al. (2014) identified eight dimensions for the servant leadership measure: empowerment, responsibility, standing back, humility, authenticity, courage, forgiveness and stewardship. These authors found that forgiveness factor loadings were the lowest in the case of Spain and Mexico. Since a similar pattern was found in studies in Italy (Bobbio et al., 2012) and The Netherlands (Van Dierendonck and Nuijten, 2011), Rodríguez-Carvajal (2014) considered this dimension should be reconsidered. In our research, this dimension was initially included in the questionnaire but on conducting CFA analysis it was not found to be significant and was thus removed from the subsequent analyses used to test the hypothesised model. Table 1 shows the items that were included in this scale. Cronbach's alpha for each subdimension varies from 0.77 to 0.95 , showing an average value of 0.86 .

PLACE TABLE 1 HERE

\subsubsection{Corporate social responsibility to employees}


Turker (2009) developed a measure of CSR reflecting the responsibilities of a business to various stakeholders and the results provided a four-dimensional structure of CSR, including CSR to social and non-social stakeholders, employees, customers and government. In this research we adopted the subscale CSR to employees, which was measured by Turker (2009) using a five-item scale comprised of the following items: (1) Our company policies encourage employees to develop their skills and careers, (2) The management of our company is primarily concerned with employees' needs and wants, (3) Our company implements flexible policies to provide a good work and life balance for its employees, (4) The managerial decisions related to employees are usually fair, and (5) Our company supports employees who want to acquire additional education. Cronbach's alpha for this measure is 0.91 .

\subsubsection{Firm innovativeness}

The measure of innovativeness is based on Calantone et al. (2002) and yields a Cronbach's alpha value of 0.85 . This scale is composed of four items: (1) Our company frequently tries out new ideas, (2) Our company seeks out new ways of doing things, (3) Our company is creative in its methods of operation, and (4) Our company is often the first to market new products and services.

\subsection{Control variables}

Based on previous research (e.g. Beugelsdijk, 2008; Cabello-Medina, 2011), annual turnover, number of employees, export intensity and age of the company (measured in years since foundation) have been used as control variables because they 
may be related to firm innovation. More specifically, large firms may have access to more resources, which affects their ability to innovate, and therefore annual turnover and number of employees were used to control for firm size. In addition, the age of the firm was also included to control for any advantages associated with increased time for the evolution or adoption of HRM practices (Guthrie, 2001).

\subsection{Analyses}

Structural equations and the statistical software AMOS 23 were used to empirically validate the conceptual model depicted in Figure 1. This software was chosen because it allows the use of bootstrapping to test the significance of the proposed indirect effect. Descriptive statistics and psychometric properties of the measurement scales were assessed using SPSS 23.

\section{Results}

\subsection{Descriptive statistics and psychometric properties of the measurement scales}

Table 2 summarises means, standard deviations and factor correlations of the constructs involved in the study.

PLACE TABLE 2 HERE 
The psychometric properties of the measurement scales were evaluated by following accepted practices in the literature (Anderson \& Gerbing, 1988), namely, by studying their dimensionality, reliability, and content, convergent and discriminant validity.

In the case of the servant leadership construct, we tested the fit of the second-order factor model (Fig. 2) to support the proposed multidimensionality of this concept, with acceptable results (Chi square $(\mathrm{df})=729.59(313) ; \mathrm{p}$-value $=0.00 ;$ Chi-square $/ \mathrm{df}=2.33$; $\mathrm{NFI}=0.870 ; \mathrm{NNFI}=0.911 ; \mathrm{CFI}=0.921 ; \mathrm{RMSEA}=0.068)$.

\section{PLACE FIGURE 2 HERE}

Regarding the structure of the constructs, in addition to Confirmatory Factor Analyses (CFA), we also followed the more commonly used approach (advocated by Anderson \& Gerbing, 1988) of assessing a full measurement model that include all the variables $($ Chi square $(\mathrm{df})=1062.24(580) ; \mathrm{p}=0.00 ; \mathrm{NFI}=0.855 ; \mathrm{NNFI}=0.922 ; \mathrm{CFI}=$ 0.928; RMSEA $=0.054)$. Moreover, all the standardised estimates were significant and in the expected direction.

The results of the reliability analysis (Table 3) were also satisfactory. Cronbach's alpha coefficient and compound reliability showed a minimum value of 0.77 , therefore above the recommended cut-off values of 0.7 (Nunnally, 1978). Average variance extracted was in all cases higher than the recommended value of 0.5 , suggesting an acceptable reliability. 


\section{PLACE TABLE 3 HERE}

The procedure followed to select the measurement scales supports content validity. All the scales used in the study were grounded in the academic literature. The servant leadership scale was based on a previous study by Rodríguez-Carvajal (2014). CSRE was measured using the five-item scale proposed by Turker (2009). Finally, the measure of innovativeness was based on Calantone (2002).

Servant leadership, CSRE and firm innovativeness CFA analyses showed that all factor loadings were significant and presented a value for NFI higher than 0.9 , which suggests strong convergent validity.

Data also met the requirements for discriminant validity, since the square root of the average variance extracted (ranging from 0.76 to 0.82 ) was greater than the construct correlations (whose maximum value is 0.72 ).

As previously explained, the influence of common method variance was tackled in the questionnaire design stage (Chang et al., 2010) by asking the human resource manager about the independent variable (servant leadership) and the general manager about the dependent variables (CSRE and firm innovativeness). In addition, two other expost analyses were performed: Harman's single factor test and common latent factor technique (CLF). Regarding Harman's test, all the variables were merged into one factor and results showed poor fit (Chi square $(\mathrm{df})=4,178.09(594) ; \mathrm{p}=0.00 ; \mathrm{NFI}=0.429$; $\mathrm{NNFI}=0.432 ; \mathrm{CFI}=0.464 ; \mathrm{RMSEA}=0.146)$, which suggested that common method bias was not a problem in this research. The common latent factor technique (e.g. Johnson et al., 2011) involves the introduction of a new latent variable in such a way that all the 
manifest variables are related to it. This technique suggests that there is no significant common method bias in these data, since the calculated variance (19\%) is below $50 \%$.

\subsection{Testing the research hypotheses}

Figures 3 and 4 show the causal model we tested and include standardised parameter values for the various linkages. The overall fit statistics of the mediation causal model were good (chi-square (df): 1204.09 (716); p-value: 0.000; chi-square/df: 1.68; NFI: 0.853; NNFI: 0.928; CFI: 0.934; RMSEA: 0.049). Although the p-value is below the recommended value, all other indicators of global fit are good, so we conclude that the global fit of this model is acceptable.

The standardised estimates were significant and in the expected direction, except for the control variables (annual turnover, number of employees, firm age and export intensity), which were non-significant.

Results show that the previous direct relationship between servant leadership and firm innovativeness decreased (and became non-significant) when the mediator, CSRE, was included. Apart from that, the indirect effect model shown in Figure 4 points to (1) a positive relationship between servant leadership and CSRE, and (2) a positive relationship between CSRE and firm innovativeness. In addition, the mediated model explains more variance than the one resulting from the model without a mediator ( $6 \% \mathrm{vs} .51 \%)$.

In order to confirm that the indirect effect is significant, a bootstrap analysis was performed (MacKinnon et al., 2012). The estimated indirect effect of servant leadership on firm innovativeness is 0.222 . The $95 \%$ bias-corrected confidence intervals for the indirect effect are between 0.107 and 0.349 , with a p-value of 0.001 for the two-tailed 
significance test. Thus, the estimated indirect effect is significantly different from zero and the null hypothesis of no mediation effect can be rejected. Consequently, the effects of servant leadership on firm innovativeness are fully mediated by CSRE.

\section{PLACE FIGURE 3 HERE}

\section{PLACE FIGURE 4 HERE}

\section{Discussion}

From a theoretical point of view, our results provide evidence of the importance of servant leadership in promoting corporate social responsibility to employees, which in turn fosters firm innovativeness.

This study proposes the following implications to help managers to increase firm innovativeness. Managers interested in increasing firm innovativeness within organisations should focus on the different leadership behaviours related to servant leadership: empowerment, servitude, accountability, courage, authenticity, humility and stewardship. Specifically, they should pay more attention to selecting people characterised by these dimensions and capable of extending their positive attitude to the rest of the employees. Moreover, they should focus training and promotion in accordance with these dimensions. 
According to our results, servant leadership may facilitate employee-based CSR actions, which, in addition to having an impact on the company's ability to innovate, have also been shown to influence a greater sense of belonging, higher levels of trust and commitment, and increased participation of employees or job satisfaction. Therefore, promoting CSR to employees might be a way to improve the firm's reputation and, thus, not only retain but also attract talented people.

Specific methodological limitations must be recognised in the present study. First, we administered the questionnaire only to managers (CEOs and HR managers), and therefore leaders estimate their own leadership behaviour. Although there are other studies that follow the same approach (e.g. Garber et al., 2009), future research should collect data taking into account other stakeholders, mainly employees. The present study is cross-sectional and it would be interesting to study the development of the interaction between leaders and followers, which calls for longitudinal and multilevel studies. Apart from overcoming these limitations, further research could also expand upon the results of this paper by considering the influence of servant leadership on different types of innovation (e.g. radical/incremental) or different phases of the innovation process (e.g. idea-generation, idea-promotion, idea-realisation and implementation stages). In addition, a combination of objective (such as share of new products and patents) and subjective (managerial/employee) measures of innovation would also be advisable.

Furthermore, future research should be developed in other cultural contexts, since servant leadership or employee-based CSR is more likely to occur in some countries than others, depending on their orientation towards people, a greater or lesser power distance, as well as different legislation in labour matters. 


\section{References}

Anderson, J. C., \& Gerbing, D. W. (1988). Structural equation modeling in practice: A review and recommended two-step approach. Psychological bulletin, 103(3), 411423.

Anthony Wong, I., \& Hong Gao, J. (2014). Exploring the direct and indirect effects of CSR on organizational commitment: the mediating role of corporate culture. International Journal of Contemporary Hospitality Management, 26(4), 500-525.

Aragón-Correa, J. A., García-Morales, V. J., \& Cordón-Pozo, E. (2007). Leadership and organizational learning's role on innovation and performance: Lessons from Spain. Industrial marketing management, 36(3), 349-359.

Atuahene-Gima, K. (2003). The effects of centrifugal and centripetal forces on product development speed and quality: How does problem solving matter?. Academy of Management Journal, 46(3), 359-373.

Bammens, Y. P. (2016). Employees' innovative behavior in social context: A closer examination of the role of organizational care. Journal of Product Innovation Management, 33(3), 244-259.

Barbuto Jr, J. E., Gottfredson, R. K., \& Searle, T. P. (2014). An examination of emotional intelligence as an antecedent of servant leadership. Journal of Leadership \& Organizational Studies, 21(3), 315-323.

Beugelsdijk, S. (2008). Strategic human resource practices and product innovation. Organization Studies, 29(6), 821-847.

Bobbio, A., Dierendonck, D. V., \& Manganelli, A. M. (2012). Servant leadership in Italy and its relation to organizational variables. Leadership, 8(3), 229-243.

Bowen, H.R. (1953), Social Responsibilities of the Business, New York: Harper \& Row. 
Calantone, R. J., Cavusgil, S. T., \& Zhao, Y. (2002). Learning orientation, firm innovation capability, and firm performance. Industrial Marketing Management, 31(6), 515524.

Caldwell, C., \& Dixon, R. D. (2010). Love, forgiveness, and trust: Critical values of the modern leader. Journal of Business Ethics, 93(1), 91-101.

Celma, D., Martínez-Garcia, E., \& Coenders, G. (2014). Corporate social responsibility in human resource management: an analysis of common practices and their determinants in Spain. Corporate Social Responsibility and Environmental Management, 21(2), 82-99.

Chang, S. J., Van Witteloostuijn, A., \& Eden, L. (2010). From the editors: Common method variance in international business research. Journal of International Business Studies, 41(2), 178-184.

Chen, C., Chen, Y., Hsu, P. H., \& Podolski, E. J. (2016). Be nice to your innovators: Employee treatment and corporate innovation performance. Journal of corporate finance, 39, 78-98.

Chen, J., Leung, W. S., \& Evans, K. P. (2016b). Are employee-friendly workplaces conducive to innovation? Journal of Corporate Finance, 40, 61-79.

Choudhary, A. I., Akhtar, S. A., \& Zaheer, A. (2013). Impact of transformational and servant leadership on organizational performance: A comparative analysis. Journal of Business Ethics, 116(2), 433-440

Christensen, L. J., Mackey, A., \& Whetten, D. (2014). Taking responsibility for corporate social responsibility: The role of leaders in creating, implementing, sustaining, or avoiding socially responsible firm behaviors. The Academy of Management Perspectives, 28(2), 164-178. 
Conger, J. A., \& Kanungo, R. N. (1988). The empowerment process: Integrating theory and practice. Academy of Management Review, 13(3), 471-482.

Delgado Ferraz, F. A., \& Gallardo-Vázquez, D. (2016). Measurement tool to assess the relationship between corporate social responsibility, training practices and business performance. Journal of Cleaner Production, 129, 659-672.

Flammer, C., \& Luo, J. (2017). Corporate social responsibility as an employee governance tool: Evidence from a quasi-experiment. Strategic Management Journal, 38(2), 163-183.

Flynn, C. B., Smither, J. W., \& Walker, A. G. (2016). Exploring the relationship between leaders' core self-evaluations and subordinates' perceptions of servant leadership: a field study. Journal of Leadership \& Organizational Studies, 23(3), 260-271.

Garber, J. S., Madigan, E. A., Click, E. R., \& Fitzpatrick, J. J. (2009). Attitudes towards collaboration and servant leadership among nurses, physicians and residents. Journal of Interprofessional Care, 23(4), 331-340.

Gilley, J. W., Shelton, P. M., \& Gilley, A. (2011). Developmental leadership: A new perspective for human resource development. Advances in Developing Human Resources, 13(3), 386-405.

González, X., Miles-Touya, D., \& Pazó, C. (2016). R\&D, worker training and innovation: Firm-level evidence. Industry and Innovation, 23(8), 694-712.

Graham, J. W. (1991). Servant-leadership in organizations: Inspirational and moral. The Leadership Quarterly, 2(2), 105-119.

Guthrie, J. P. (2001). High-involvement work practices, turnover, and productivity: Evidence from New Zealand. Academy of management Journal, 44(1), 180-190. 
Hind, P., Wilson, A., \& Lenssen, G. (2009). Developing leaders for sustainable business. Corporate Governance: The International Journal of Business in Society, 9(1), 720.

Hunter, E. M., Neubert, M. J., Perry, S. J., Witt, L. A., Penney, L. M., \& Weinberger, E. (2013). Servant leaders inspire servant followers: Antecedents and outcomes for employees and the organization. The Leadership Quarterly, 24(2), 316-331.

James, A. (2014). Work-life 'balance', recession and the gendered limits to learning and innovation (or, why it pays employers to care). Gender, Work \& Organization, 21(3), 273-294.

Johnson, R. E., Rosen, C. C., \& Djurdjevic, E. (2011). Assessing the impact of common method variance on higher order multidimensional constructs. Journal of Applied Psychology, 96(4), 744-761.

Khazanchi, S., Lewis, M. W., \& Boyer, K. K. (2007). Innovation-supportive culture: The impact of organizational values on process innovation. Journal of operations management, 25(4), 871-884.

Kuppelwieser, V. G. (2011). Stewardship behavior and creativity. Management Revue, 274-295.

Liden, R. C., Wayne, S. J., Liao, C., \& Meuser, J. D. (2014). Servant leadership and serving culture: Influence on individual and unit performance. Academy of Management Journal, 57(5), 1434-1452.

MacKinnon, D. P., Coxe, S., \& Baraldi, A. N. (2012). Guidelines for the investigation of mediating variables in business research. Journal of Business and Psychology, $27(1), 1-14$.

Mishra, D. R. (2017). Post-innovation CSR performance and firm value. Journal of Business Ethics, 140(2), 285-306. 
Mishra, S., \& Modi, S. B. (2016). Corporate social responsibility and shareholder wealth: The role of marketing capability. Journal of Marketing, 80(1), 26-46.

Müceldili, B., Turan, H., \& Erdil, O. (2013). The influence of authentic leadership on creativity and innovativeness. Procedia-Social and Behavioral Sciences, 99, 673681.

Mumford, M. D., Scott, G. M., Gaddis, B., \& Strange, J. M. (2002). Leading creative people: Orchestrating expertise and relationships. The Leadership Quarterly, 13(6), 705-750.

Newman, A., Miao, Q., Hofman, P. S., \& Zhu, C. J. (2016). The impact of socially responsible human resource management on employees' organizational citizenship behaviour: the mediating role of organizational identification. The International Journal of Human Resource Management, 27(4), 440-455.

Nunnally, J. C. (1978). Psychometric theory, New York: McGraw-Hill

Nutt, P. C. (2002). Why decisions fail: Avoiding the blunders and traps that lead to debacles. San Francisco: Berrett-Koehler.

Panaccio, A., Henderson, D. J., Liden, R. C., Wayne, S. J., \& Cao, X. (2015). Toward an understanding of when and why servant leadership accounts for employee extrarole behaviors. Journal of Business and Psychology, 30(4), 657-675.

Peterson, S. J., Galvin, B. M., \& Lange, D. (2012). CEO servant leadership: Exploring executive characteristics and firm performance. Personnel Psychology, 65(3), 565596.

Prasad, B., \& Junni, P. (2017). A contingency model of CEO characteristics and firm innovativeness: The moderating role of organizational size. Management Decision, $55(1), 156-177$ 
Prasad, B., \& Martens, R. (2015). Top management team advice-seeking and environmental competitiveness impacts on technological innovation. International Journal of Technology Management, 69(1), 77-92.

Rodrigo, P., \& Arenas, D. (2008). Do employees care about CSR programs? A typology of employees according to their attitudes. Journal of Business Ethics, 83(2), 265283.

Rodríguez-Carvajal, R., de Rivas, S., Herrero, M., Moreno-Jiménez, B., \& Van Dierendonck, D. (2014). Leading people positively: cross-cultural validation of the servant leadership survey (SLS). The Spanish journal of psychology, 17.

Seibert, S. E., Wang, G., \& Courtright, S. H. (2011). Antecedents and consequences of psychological and team empowerment in organizations: a meta-analytic review, 96(5), 981-1003.

Sendjaya, S., Sarros, J. C., \& Santora, J. C. (2008). Defining and measuring servant leadership behaviour in organizations. Journal of Management Studies, 45(2), 402424.

Shevchenko, A., Lévesque, M., \& Pagell, M. (2016). Why firms delay reaching true sustainability. Journal of Management Studies, 53(5), 911-935.

Stone, M. (2002). Forgiveness in the workplace. Industrial and Commercial Training, 34(7), 278-286.

Topcu, M. K., Gursoy, A., \& Gurson, P. (2015). The Role of the Servant Leadership on the Relation between Ethical Climate Perception and Innovative Work. European Research Studies, 18(1), 67.

Turker, D. (2009). Measuring corporate social responsibility: A scale development study. Journal of Business Ethics, 85(4), 411-427. 
Van Dierendonck, D. (2011). Servant leadership: A review and synthesis. Journal of Management, 37(4), 1228-1261.

Van Dierendonck, D., \& Nuijten, I. (2011). The servant leadership survey: Development and validation of a multidimensional measure. Journal of Business and Psychology, 26(3), 249-267.

Van Dierendonck, D., \& Patterson, K. (2015). Compassionate love as a cornerstone of servant leadership: An integration of previous theorizing and research. Journal of Business Ethics, 128(1), 119-131.

Varadarajan, R. (2009). Fortune at the bottom of the innovation pyramid: The strategic logic of incremental innovations. Business Horizons, 52(1), 21-29.

Williams Jr, W. A., Williams Jr, W. A., Brandon, R. S., Brandon, R. S., Hayek, M., Hayek, M., \& Atinc, G. (2017). Servant leadership and followership creativity: The influence of workplace spirituality and political skill. Leadership \& Organization Development Journal, 38(2), 178-193.

Yang, J., Liu, H., \& Gu, J. (2017). A multi-level study of servant leadership on creativity: the roles of self-efficacy and power distance. Leadership \& Organization Development Journal, 38(5).

Yoshida, D. T., Sendjaya, S., Hirst, G., \& Cooper, B. (2014). Does servant leadership foster creativity and innovation? A multi-level mediation study of identification and prototypicality. Journal of Business Research, 67(7), 1395-1404. 


\section{Tables}

Table 1. Servant leadership measure (Based on Rodríguez-Carvajal, 2014)

Emporwerment

\begin{tabular}{ll}
\hline EMP1 & The leaders of this company give the information that people need to be able to do their job well. \\
\hline EMP2 & The leaders of this company encourage people to use their skills and knowledge. \\
\hline EMP3 & Thanks to the leaders of this company, people have been able to develop more as professionals. \\
\hline EMP4 & The leaders of this company encourage their team to develop new ideas. \\
\hline EMP5 & $\begin{array}{l}\text { The leaders of this company give the authority that people need to make decisions that facilitate } \\
\text { their work. }\end{array}$ \\
\hline EMP6 & $\begin{array}{l}\text { The leaders of this company try to give support to people to find their own solutions instead of } \\
\text { telling them directly what they should do. }\end{array}$ \\
\hline EMP7 & The leaders of this company give many opportunities to people to develop new skills. \\
\hline
\end{tabular}

\section{Servitude}

SER1 The leaders of this company work 'behind the scenes' and let others take praise.

SER2 The leaders of this company do not seek any recognition or reward in the things they do for others.

SER3 The leaders of this company rejoice more for the good performance of others than for their own.

\begin{tabular}{ll} 
Accountability \\
\hline ACC1 & The leaders of this company make people responsible for the work they carry out. \\
\hline ACC2 & $\begin{array}{l}\text { The people of this company are responsible for its performance (thanks to the leaders of this } \\
\text { company). }\end{array}$ \\
\hline ACC3 & The leaders of this company make people responsible for how their work is organized. \\
Courage & $\begin{array}{l}\text { The leaders of this company take risks even when they are not sure if they have the support of } \\
\text { their supervisors. }\end{array}$ \\
\hline COU2 & The leaders of this company take risks if necessary to do what they believe should be done.
\end{tabular}

Authenticity

AUT1 The leaders of this company show their limitations and weaknesses.

AUT2 The leaders of this company are moved by the things that happen around them.

AUT3 The leaders of this company are willing to express their feelings even if they lead to undesirable consequences.

AUT4 The leaders of this company show their true feelings to their employees.

\begin{tabular}{ll}
\multicolumn{2}{l}{ Humility } \\
\hline HUM1 & The leaders of this company learn from criticism. \\
\hline HUM2 & $\begin{array}{l}\text { The leaders of this company try to learn from criticism from others, including their own } \\
\text { supervisors. }\end{array}$ \\
\hline HUM3 & The leaders of this company admit their mistakes to others, including their own supervisors. \\
\hline HUM4 & The leaders of this company learn from those who think differently. \\
\hline HUM5 & If people express criticism openly, the leaders of this company try to learn from it. \\
Stewardship \\
\hline STE1 & The leaders of this company emphasize the importance of paying attention to the common good. \\
\hline STE2 & The leaders of this company work with a long-term perspective. \\
\hline STE3 & The leaders of this company emphasize the social responsibility of our work. \\
\hline
\end{tabular}


Table 2. Means, standard deviations and factor correlations

\begin{tabular}{|c|c|c|c|c|c|c|c|c|c|c|c|}
\hline Concept & Mean & SD & 1 & 2 & 3 & 4 & 5 & 6 & 7 & 8 & 9 \\
\hline 1. SL (†): Empowerment & 5.37 & 0.90 & 1 & & & & & & & & \\
\hline 2. SL: Servitude & 4.78 & 1.10 & $.42 * *$ & 1 & & & & & & & \\
\hline 3. SL: Accountability & 5.31 & 0.88 & $.52^{* *}$ & $.45^{* *}$ & 1 & & & & & & \\
\hline 4. SL: Courage & 4.81 & 1.02 & $.18^{* *}$ & $.20 * *$ & $.25^{* *}$ & 1 & & & & & \\
\hline 5. SL: Authenticity & 4.60 & 1.05 & $.29 * *$ & $.41^{* *}$ & $.24^{* *}$ & $.38 * *$ & 1 & & & & \\
\hline 6. SL: Humility & 5.04 & 1.01 & $.57^{* *}$ & $.44^{* *}$ & $.43^{* *}$ & $.26^{* *}$ & $.52 * *$ & 1 & & & \\
\hline 7. SL: Stewardship & 5.28 & 0.99 & $.51 * *$ & $.43^{* *}$ & $.43 * *$ & $.25^{* *}$ & $.41 * *$ & $.72^{* *}$ & 1 & & \\
\hline 8. CSRE ( $\ddagger)$ & 5.61 & 0.92 & $.17^{* *}$ & $.15^{*}$ & $.21 * *$ & $.13^{*}$ & $.21 * *$ & $.25^{*}$ & $.24^{* *}$ & 1 & \\
\hline 9. Firm innovativeness & 5.50 & 0.95 & $.20 * *$ & .02 & $.15^{*}$ & .04 & .05 & $.16^{* *}$ & $.14^{*}$ & $.61^{* *}$ & 1 \\
\hline
\end{tabular}

+ SL: Servant Leadership

¥ CSRE: Corporate social responsibility to employees

$\mathrm{n}=285$

$* \mathrm{p}<0.05$

$* * p<0.01$

Table 3. Servant leadership, corporate social responsibility to employees and firm innovativeness: Cronbach's alpha, composite reliability and average variance extracted

\begin{tabular}{|c|c|c|c|}
\hline Construct & $\begin{array}{c}\text { Cronbach's } \\
\text { alpha }\end{array}$ & $\begin{array}{c}\text { Composite } \\
\text { reliability }\end{array}$ & $\begin{array}{c}\text { Average } \\
\text { variance } \\
\text { extracted } \\
\text { (AVE) }\end{array}$ \\
\hline Servant leadership: Empowerment & 0.94 & 0.93 & 0.66 \\
\hline Servant leadership: Servitude & 0.79 & 0.81 & 0.60 \\
\hline Servant leadership: Accountability & 0.83 & 0.83 & 0.61 \\
\hline Servant leadership: Courage & 0.77 & 0.76 & 0.62 \\
\hline Servant leadership: Authenticity & 0.86 & 0.84 & 0.58 \\
\hline Servant leadership: Humility & 0.93 & 0.91 & 0.68 \\
\hline Servant leadership: Stewardship & 0.85 & 0.83 & 0.62 \\
\hline Corporate social responsibility to employees & 0.91 & 0.89 & 0.62 \\
\hline Firm innovativeness & 0.85 & 0.85 & 0.61 \\
\hline
\end{tabular}




\section{Figures}

Figure 1. Conceptual model

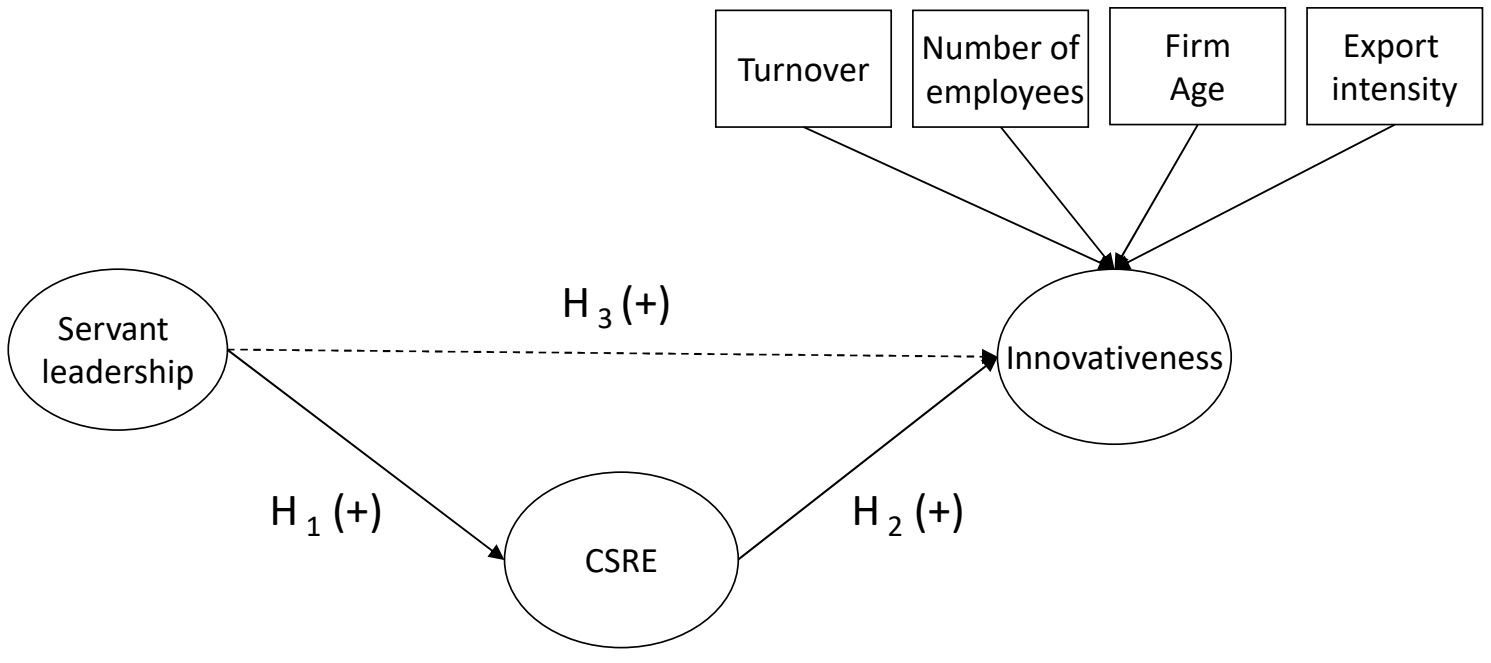

Figure 2. Servant leadership CFA analysis
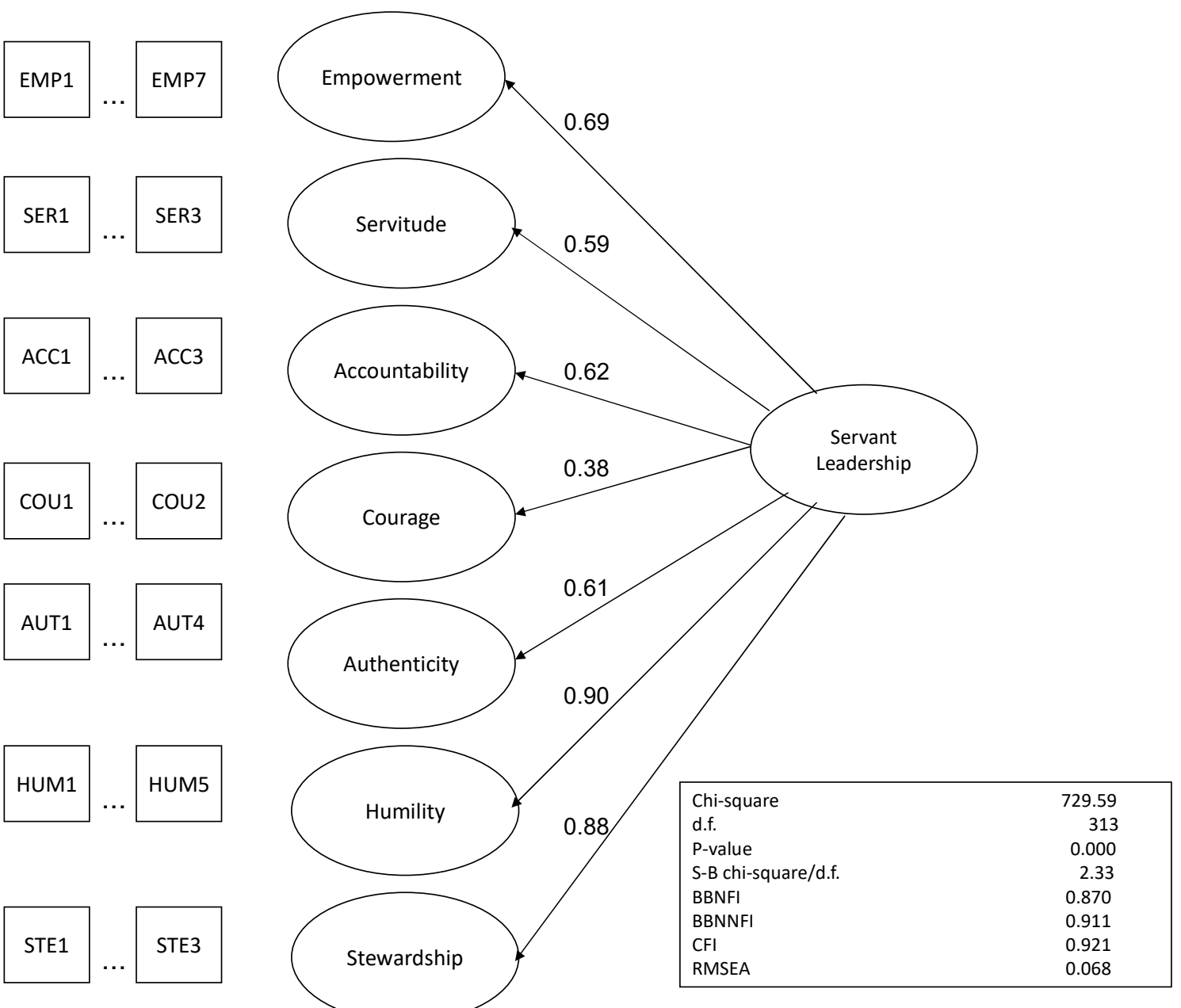
Figure 3. Total effect model (without the mediator variable)

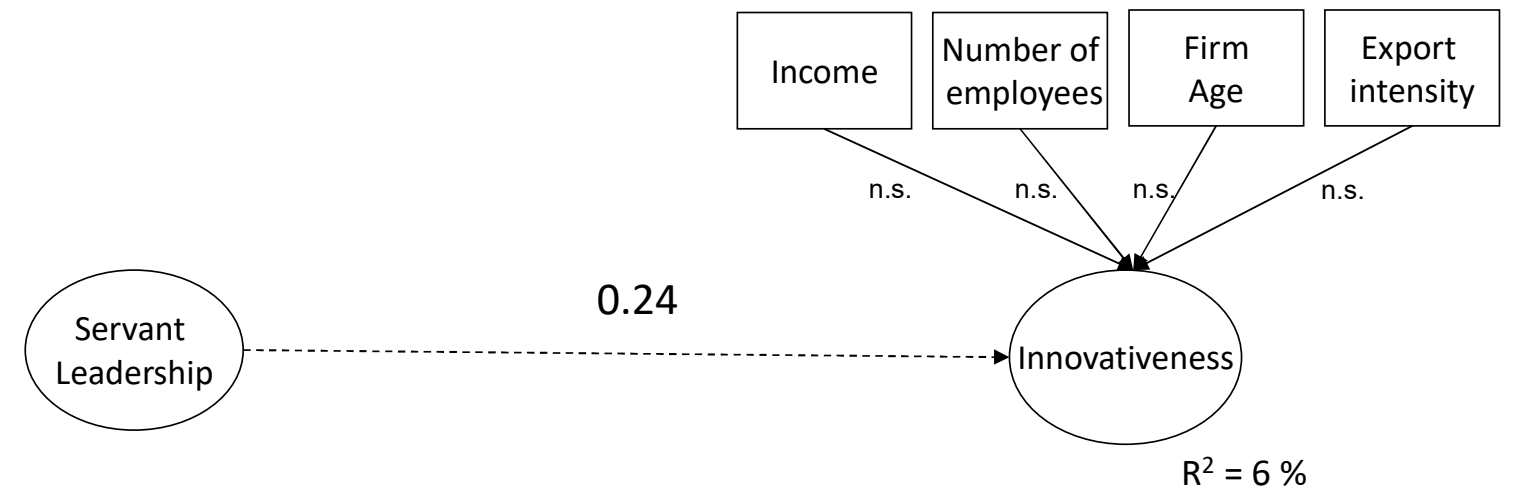

\begin{tabular}{|lr|}
\hline Chi-square & 951.34 \\
d.f. & 538 \\
P-value & 0.000 \\
S-B chi-square/d.f. & 1.77 \\
BBNFI & 0.865 \\
BBNNFI & 0.929 \\
CFI & 0.936 \\
RMSEA & 0.052 \\
\hline
\end{tabular}

Figure 4. Results of the mediated model

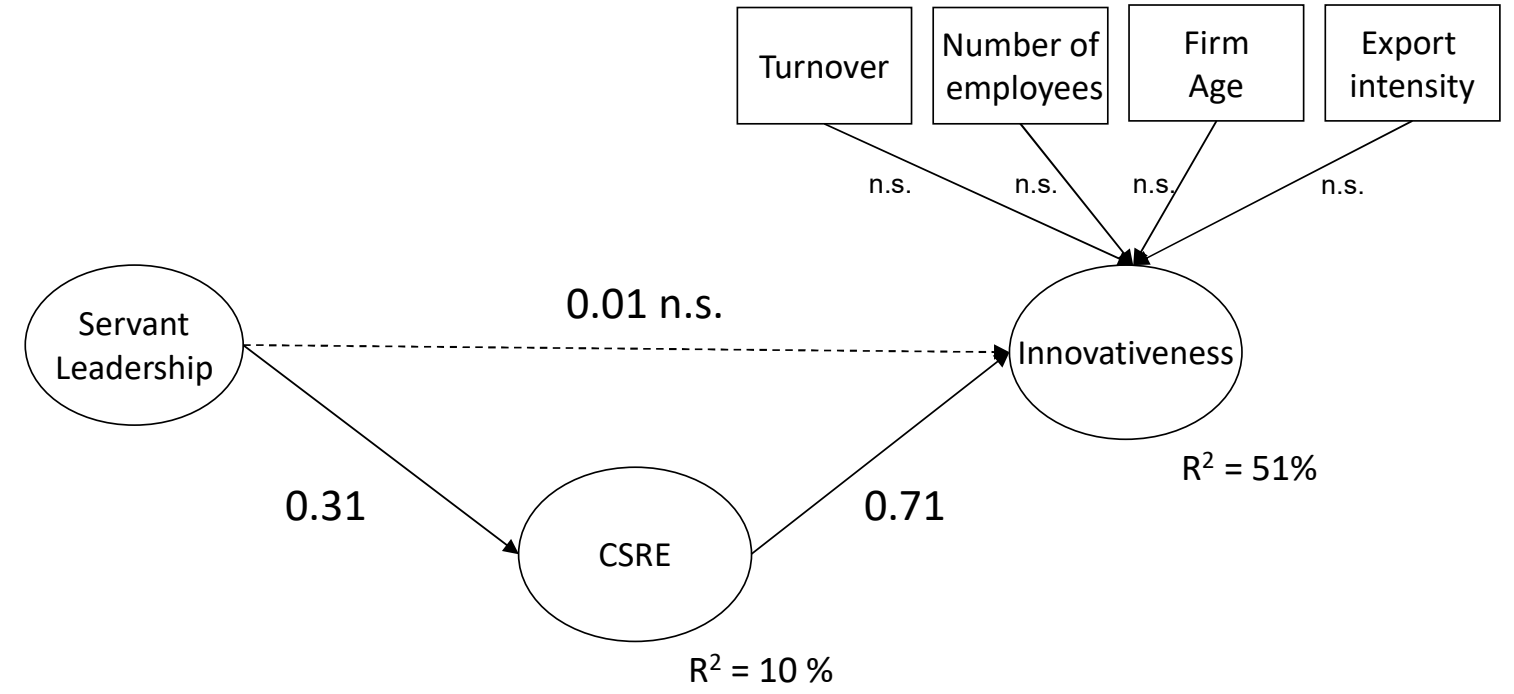

\begin{tabular}{|lr|}
\hline Chi-square & 1204.09 \\
d.f. & 716 \\
P-value & 0.000 \\
S-B chi-square/d.f. & 1.62 \\
BBNFI & 0.853 \\
BBNNFI & 0.928 \\
CFI & 0.934 \\
RMSEA & 0.049 \\
\hline
\end{tabular}

